\title{
A Novel Solution for Severe Loss Prevention While Drilling Deep Wells
}

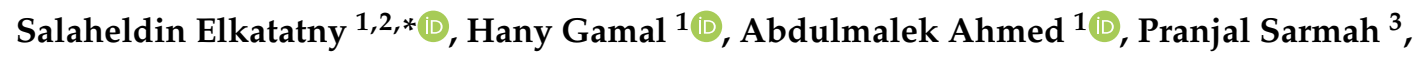 \\ Shiv Sangaru ${ }^{3}{ }^{-1}$ and Maryam Alohaly ${ }^{3}$ \\ 1 College of Petroleum Engineering \& Geosciences, King Fahd University of Petroleum \& Minerals, \\ Dhahran 31261, Saudi Arabia; g201706870@kfupm.edu.sa (H.G.); g201080240@kfupm.edu.sa (A.A.) \\ 2 College of Engineering, Department of Mining, Petroleum and Metallugy, Cairo University, \\ Cairo 11435, Egypt \\ 3 Baker Hughes, Dhahran 31952, Saudi Arabia; Pranjal.Sarmah@bakerhughes.com (P.S.); \\ ShivShankar.Sangaru@bakerhughes.com (S.S.); Maryam.Alohaly@bakerhughes.com (M.A.) \\ * Correspondence: elkatatny@kfupm.edu.sa; Tel.: +966-594-663-692
}

Received: 24 December 2019; Accepted: 9 February 2020; Published: 12 February 2020

check for updates

\begin{abstract}
The loss of circulation is a big problem in drilling operations. This problem is costly, time-consuming and may lead to a well control situation. Much research has investigated the effectiveness of using different chemicals as lost circulation material (LCM) to stop mud and cement slurry losses. However, there remain many limitations for using such LCM types, especially when it comes to field applications. This paper presents a new high strength lost circulation material (HSLCM) that could effectively be used for managing severe lost circulation cases. The HSLCM could easily be pumped into the thief zone where it forms a gel that solidifies after a setting time to provide sealing between the wellbore and the thief zone. With this technique, the material stops the circulation losses, and hence enhances the well bore stability by reducing the well bore stresses. The HSLCM has a high compressive strength and it has a high acid solubility of around $96 \%$. Because the HSLCM has high tolerance towards contamination, it can be utilized with water-based mud or invert emulsion-drilling fluids, hence providing a wide window of applications with the drilling fluids. In this study, laboratory experiments were conducted to evaluate the rheology, thickening time, compressive strength, and acid solubility of the HSLCM. The results showed good performance for the HSLCM as LCM. In addition, a case field study is presented which shows a successful field treatment for severe losses.
\end{abstract}

Keywords: lost circulation material; high strength; acid soluble pill; severe losses

\section{Introduction}

Many challenges are encountered while drilling deep and high-pressure high-temperature (HPHT) wells. One of the most severe, costly, and time-consuming problems in drilling operations is the lost circulation. Circulation loss or loss of return is known as the partial or complete loss of drilling fluid or cement slurry from the annulus into the formation at any depth [1], which occurs when the wellbore pressure is greater than the fracture pressure with the presence of a flow pathway $[2,3]$.

There are four types of losses based on its severity: seepage, partial, severe, and total [4]. Loss of circulation may occur for any type of formation, as this issue has been encountered in many rock types at different depths [5]. Some of the formations have more chances to be invaded by fluids, such as naturally or induced fractured formations, unconsolidated zones, cavernous and vugular zones, and high permeability formations. The losses in these formations are defined based on the path and speed of the fluid when it exits the wellbore [6]. 
Loss of circulation has many consequences that affect the drilling operation economically and efficiently. Drilling fluids are expensive and cost the petroleum industry over $\$ 12$ billion in 2018 as indicated by the drilling mud global market [7]. The drilling fluid accounts for $25 \%-40 \%$ of the total cost of the drilling operation, so any loss of the drilling fluid will increase the total cost of the drilling operation. Uncontrolled lost circulation of the drilling fluid can result in a dangerous well control problem and in some cases also in the loss of the well [8]. It can also lead to other effects such as increasing nonproductive time, resulting in a stuck pipe because of the poor hole cleaning conditions.

\section{Lost Circulation Materials}

Different methods have been used to mitigate the lost circulation problem while drilling and during workover operations. The most common method is using solid particles, which are referred to as lost circulation materials (LCMs) to reduce and prevent any loss of circulation. The common LCMs include flaky, granular, fibrous, blended, water/acid-soluble, hydratable/swellable LCMs, nanoparticles, cement plug, polyurethane grouting, settable plugs, crosslinked gel, and viscoelastic surfactant [9-12].

Samsuri and Phuong [13] introduced a less expensive cement formulation for loss of return issues while drilling in vugular, high permeability, or naturally fractured formations. This formulation caused a reduction in the permeability of the core by $20 \%$ compared to the reduction in the permeability due to the drilling fluid $(40 \%-70 \%)$. In some cases, the reduction in the permeability due to drilling can be $80 \%-90 \%$ [14].

Bour et al. [15] stated that acid soluble cement (ASC) (foamed or neat) provides an effective solution to the loss of return through producing a formation. Seymour and Santra [16] evaluated the use of acid-soluble cement (ASC) as a solution for loss of returns in drilling the reservoir section. They concluded that the magnesium-oxychloride-cement (MOC) has unique advantages, such as a very quick setting and being $100 \%$ acid-soluble. Savari et al. [17] presented a composite LCM solution of an acid-soluble combination with a multimodal particle size distribution to handle severe to total loss of circulation in the naturally fractured formation. The laboratory results confirmed a solubility of $96 \%$ for this material in $15 \mathrm{wt} . \% \mathrm{HCl}$ and $10 \mathrm{wt} . \%$ of formic acid. The capability of the solution was tested in the laboratory and the solution was able to plug a simulated fracture of 0.5 inches.

During the cement operations, loss of the cement slurry into the formation resulted in incomplete sealing of the annulus and a remedial cement operation was required to fill the annulus [18-20]. To overcome this issue, a new technique for slurry placement called reversed-circulation placement technique (RCPT) was applied in a California geothermal well [21]. Robert et al. [22] evaluated a unique cement slurry (foamed-cement slurry) and RCPT technique and concluded that using the new technique can reduce the annular pressure and the excess cement pumped in the hole. Gupta et al. [23] reported a case study where a solution of cement plug of fiber was successfully used to treat a total loss circulation. The LCM is Class G cement extended with an advance gel-strength of bentonite, a mixture of a flake-solids package, and synthetic fibrous LCM mixed with the slurry to form a filter cake to remedy the losses.

Suyan et al. [24] stated that the cementitious compositions admixed with synthetic fibrous LCM can be utilized to avoid a loss of return when drilling a high permeable or fracture zone. Priening et al. [25] reported that the advanced engineering fibers composed of inert material are easy to disperse in the drilling fluid and can make a 3D network across the loss zone, thereby allowing the solids in the drilling fluid to form bridging plug and cure the losses. According to Droger et al. [26], the performance of fiber LCM is affected by fiber concentration, fluid viscosity, fiber geometry, fracture width, and flow rate. They concluded that degradable fiber systems are effective for preventing losses in fractures as wide as $5 \mathrm{~mm}$.

Savari et al. [27] evaluated the application of high resiliency graphitic carbon (RGC) as a lost circulation material. RGC does not interfere with logging tools or downhole equipment because it is a conductive material with no magnetic properties. RGC can impart resiliency to other LCMs [28]. Savari et al. [27] concluded that RGC was a good material to be used during drilling the reservoir 
section because it was completely inert and could be combined with acid-soluble ground marble to allow the flow to come back.

Al-Awad and Fattah [29] tested a good fracture seal material made of shredded waste car tiers in the lab to determine its ability to plug a fractured core sample under HPHT conditions. The testing proved that this LCM completely plugged the core's fracture at a high temperature of $80^{\circ} \mathrm{C}$ and a high pressure of 900 psi. Nasiri et al. [30] used many LCMs to prevent the losses in two different types of drilling muds-bentonite drilling fluid and new drilling mud that has a new additive from a famous flowered plant in Iran. Their new LCM formed a bridge that reduced the total losses. They also applied the new LCM in various types of losses in 10 wells and found that it had the ability to control losses in Gardan Oilfield.

Several studies had investigated the use of cross-linked polymers as LCM. However, because of the initiation of the cross-linking reaction at the surface, it is hard to put the cross-linked polymer slurry in the required place. Quinn et al. [31] provided a smart plug product to avoid this problem. Another disadvantage of the cross-linked polymer pill is that it can extrude easily into the fracture under the high-pressure drop. Lecolier et al. [32] introduced a new solution using cross-linked polymer gel, including swelling polymer particles and a colloidal one (nano-composite organic/inorganic gel). Metcalf et al. [33] developed a new environment preferred system to solve the fluid loss problem during drilling in the Permian Basin of West Texas. The formulation consisted of natural polymer, lost circulation material, and silicate particles. They concluded that $60 \%$ of circulation could be restored within 9 to $12 \mathrm{~h}$ using the preferred system, and $100 \%$ of circulation could be restored within 18 to $24 \mathrm{~h}$. Jiang et al. [34] used a cross-linked polymer to control the losses, which has an extended gelation time and high strength. It can withstand up to a pressure of $9.8 \mathrm{MPa}$ and a temperature of $150{ }^{\circ} \mathrm{C}$ and can seal a slot that has fracture of $3 \mathrm{~mm}$ in width.

Each type of the lost circulation materials mentioned above has some disadvantages that make it difficult to be applied. Most of these treatments need time to be prepared and placed and are hard to set at the desired location [35] to achieve high compressive strength. Some of them can affect the pumping ability, create formation damage, and need to be removed out of the hole to keep the tools safe. The other LCM has low acid solubility, is unable to be dissolved by using the conventional method such as acid, and requires a removal treatment because of the formed filter cake [36].

Whatever LCM is used, it must be consistent with the drilling mud in the wellbore. It should have the ability to go through constrictions in the bottom hole assembly (BHA). LCM should also have a slight impact on the formation permeability, particularly the producing formations. This paper will provide a new solution for the different types of losses. A new lost circulation material, which has high compressive strength and pumps easily, will be presented in this study. The performance of the new LCM was evaluated through many experiments to test its ability to control the losses; mixing, rheology, thickening or setting time, compressive strength, acid solubility, mud contaminations, and observations on the field case of using this new material will be discussed in this paper.

\section{Materials Description}

The HSLCM is a mixture of several materials prepared to achieve required properties and functions for the LCM. The HSLCM composition contains water as the base fluid, defoamer, setting control additive for set time design, viscoelastic surfactant (VES) to build the viscosity, acid soluble weighting additive (ASWA) to achieve the required density, monovalent or multivalent salt as ionic strength additive to increase the efficiency of VES, and the dispersant. The formulation forms a solid hard plug like cement when the ASWA powder reacts with water, and the reaction is retarded with the setting control additive. The density range of the HSLCM is from 10 to 14 pounds per gallon (ppg) and can be increased to a higher required density. The formulations for $12.5 \mathrm{ppg}$ fluid for the temperature range from $125^{\circ} \mathrm{F}$ to $225^{\circ} \mathrm{F}$ are presented in Table 1 . 
Table 1. The high strength lost circulation material (HSLCM) (12.5 ppg) formulations at different temperatures.

\begin{tabular}{ccccccc}
\hline Material & $\begin{array}{c}\text { Water, } \\
\mathbf{m L}\end{array}$ & $\begin{array}{c}\text { Defoamer, } \\
\mathbf{p p b}\end{array}$ & $\begin{array}{c}\text { Ionic Strength } \\
\text { Additive, ppb }\end{array}$ & $\begin{array}{c}\text { Setting Control } \\
\text { Additive, ppb }\end{array}$ & $\begin{array}{c}\text { VES, } \\
\text { ppb }\end{array}$ & $\begin{array}{c}\text { ASWA, } \\
\mathbf{p p b}\end{array}$ \\
\hline $125^{\circ} \mathrm{F}$ & 245.3 & 0.4 & 10.3 & 2.6 & 7.5 & 257.8 \\
$150^{\circ} \mathrm{F}$ & 245.5 & 0.4 & 7.7 & 5.2 & 7.5 & 257.7 \\
$175^{\circ} \mathrm{F}$ & 244.9 & 0.4 & 2.5 & 12.8 & 7.5 & 255.8 \\
$200^{\circ} \mathrm{F}$ & 240.7 & 0.4 & 2.5 & 24.8 & 7.5 & 248.4 \\
$225^{\circ} \mathrm{F}$ & 236.7 & 0.4 & 2.5 & 36.2 & 7.5 & 241.3 \\
\hline
\end{tabular}

Figure 1 presents the particle size distribution (PSD) for the ASWA. The size distribution shows that $D_{10}$ is 1.73 microns $(\mu \mathrm{m}), D_{50}$ is $12.66 \mu \mathrm{m}$, and $D_{90}$ is $172.6 \mu \mathrm{m}$. From the PSD, it is clear that no pumping problems will be encountered using the drilling bit with a nozzle size greater than $14 / 32$ inches. This can save the time and cost for an additional tripping that may be required with conventional lost circulations rig operations.

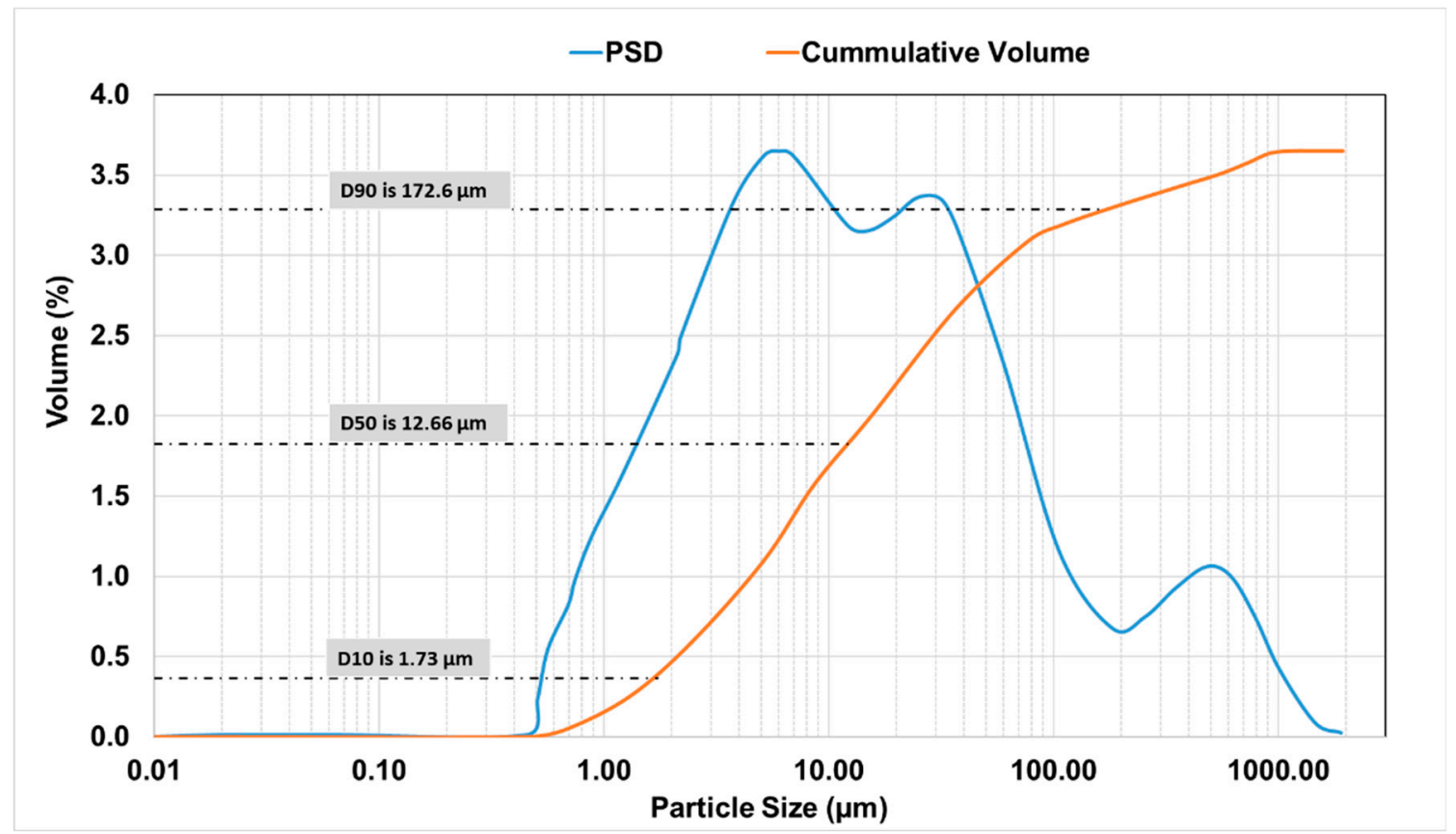

Figure 1. Particle size distribution (PSD) for acid soluble weighting additive (ASWA).

In this study, the LCM was mixed with a bottom drive mixer of blade type to prepare the fluid slurry. Figure 2 shows the mixing stages for the HSLCM as the fluid mixes easily at stage 1 and then phase transformation from fluid to solid phase at stage 2 based on the designed thickening time and temperature.

The HSLCM has a pseudo-cross-linked property because it contains an amphoteric surfactant that forms an elongated structure along with monovalent and/or divalent salts such as magnesium chloride, calcium chloride, and potassium chloride. The weighting material, ASWA, is transformed into a solid plug with high compressive strength when it reacts with water with the designed time and temperature. In addition, boron-based compound works as a retarder to control the setting time process with respect to the downhole temperature. The fluid composition does not contain crosslinking gellants. 


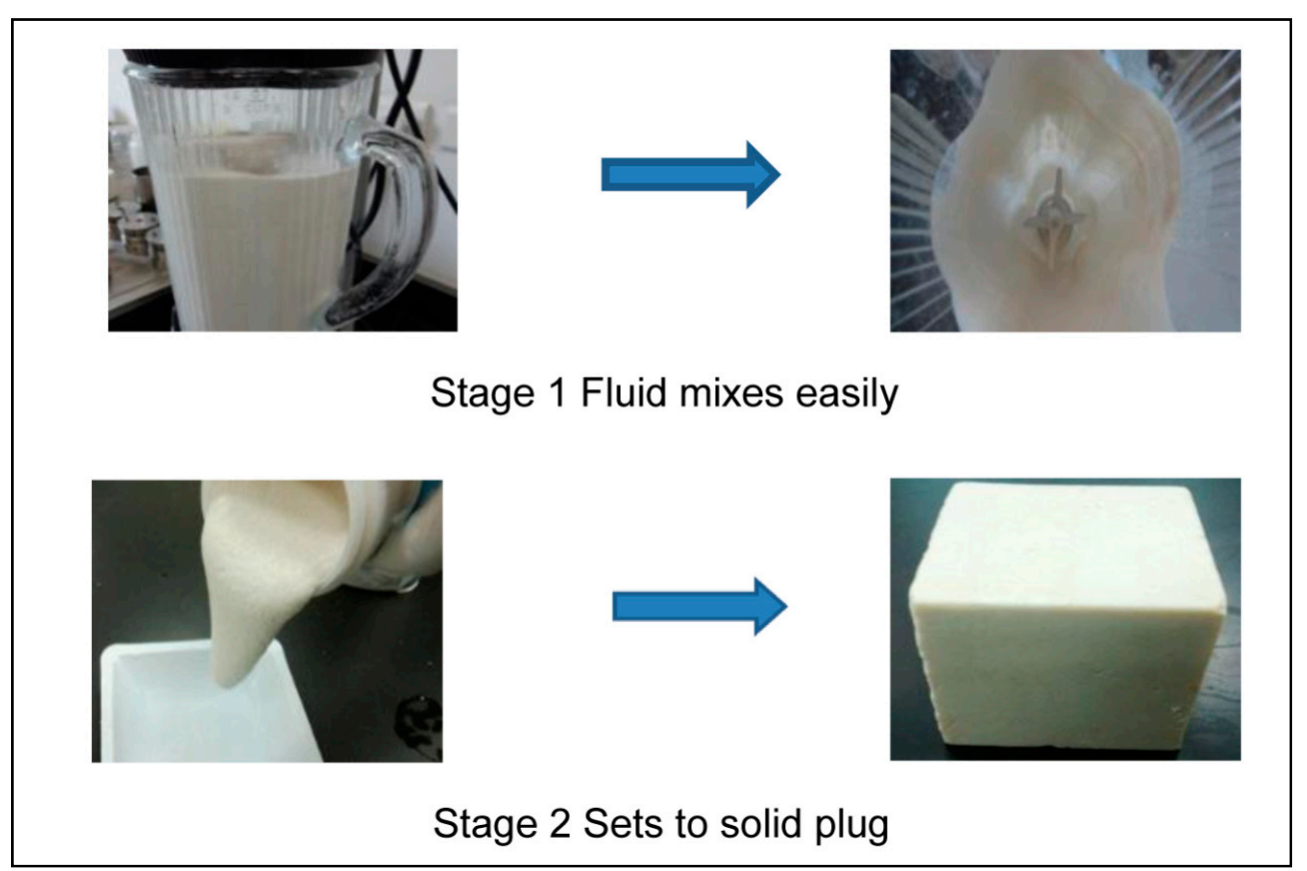

Figure 2. The HSLCM fluid mixing and phase transformation from fluid to solid phase.

\section{Experimental Program Design}

A comprehensive laboratory testing program was designed and performed to evaluate the properties of the HSLCM. The laboratory work started from the fluid mixing and evaluating the density and rheological properties of the slurry. Investigation of the thickening time, phase transformation to solid state, compressive strength for the HSLCM solid plug, and acid solubility testing for the HSLCM was also conducted. The design addressed the operation temperature and pressure conditions to evaluate the new fluid performance for field applications.

\subsection{Rheological Properties}

The HSLCM viscosity was measured using Fann 35 and Chandler Engineering Model 5550 Viscometer which is designed to measure the rheological properties of fluids at HPHT conditions and has a wide range of applications for oilfield fluids. The rheological properties include plastic viscosity (PV), yield point (YP), gel strength, and shear-stress shear-rate relation were measured at room temperature, $175^{\circ} \mathrm{F}$, and $200^{\circ} \mathrm{F}$ for the fluids with and without the VES.

\subsection{Thickening Time Test}

An HTHP consistometer was used to test the thickening time of the new LCM slurry at a downhole pressure and temperature. The thickening time of slurry was measured according to API standards by measuring the time period for which the fluid stays pumpable efficiently from surface to down-hole [37-39]. In this study, the thickening time was evaluated with a HPHT consistometer to measure the time required for the slurry to reach a consistency of 70 Bearden consistency units (Bc) for the temperature range from $125^{\circ} \mathrm{F}$ to $225^{\circ} \mathrm{F}$.

\subsection{Compressive Strength Test}

The change in the slurry compressive strength was evaluated with an ultrasonic cement analyzer (UCA). The strength measurement was based on correlations that have been developed to estimate the relative compressive strength of slurry sample based on the required time for the ultrasonic signal to pass through the slurry sample as it sets. 


\subsection{Solubility Test}

The 2-inch HSLCM solid plug cubes were prepared inside the HPHT autoclave (Figure 3) at the designed conditions of pressure and temperature ( $3000 \mathrm{psi}$ and $\left.200{ }^{\circ} \mathrm{F}\right)$. After $24 \mathrm{~h}$ of curing, the cubes were tested for acid solubility using $15 \mathrm{wt} . \%$ hydrochloric acid $(\mathrm{HCl})$. The weight of the samples was measured before and after the acid treatment to determine its acid solubility.

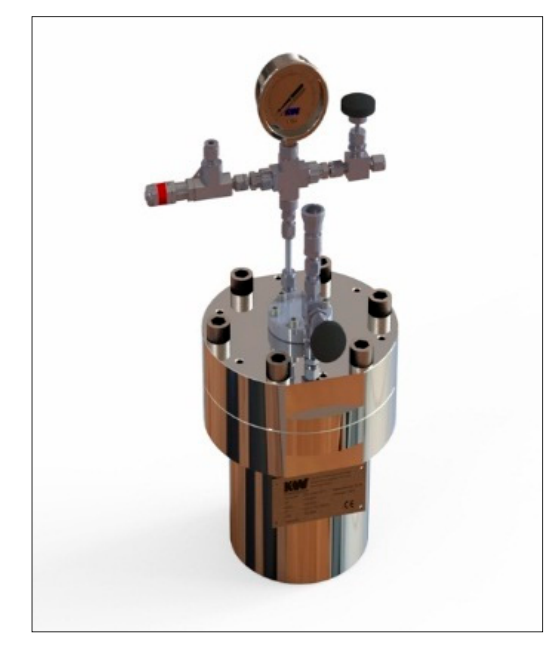

Figure 3. HPHT autoclave.

\section{Results and Discussion}

\subsection{Rheology Measurements}

The initial fluid rheological properties were performed at room temperature $\left(80^{\circ} \mathrm{F}\right)$. Figure 4 represents the shear-stress, shear-rate behavior of the new LCM fluid with and without adding VES at room temperature. Figure 5 shows the shear-stress and shear-rate for the HSLCM fluid at $175^{\circ} \mathrm{F}$. The results represented in Figures 4 and 5 show that the addition of the VES significantly increased the shear stresses of the solution at the lower shear rates, which helps to build the fluid viscosity. This effect is clearly shown in Figure 6, which compares the viscosities of the HSLCM with and without VES at $200{ }^{\circ} \mathrm{F}$. Figure 7 shows the 10-s gel strength readings for the slurry with and without VES. The addition of the VES increased the 10-s gel strength of the HSLCM fluid to more than three orders of its original value of $18 \mathrm{lb} / 100 \mathrm{ft}^{2}$ for the slurry without VES to reach $60 \mathrm{lb} / 100 \mathrm{ft}^{2}$ after adding VES. Figure 8 represents the gel strength for HSLCM with VES case at $175^{\circ} \mathrm{F}$ for 10 -s and 10-min readings, which are 37 and $98 \mathrm{lb} / 100 \mathrm{ft}^{2}$, respectively. The results show the new LCM has a good placement property because the mixed slurry has a low initial viscosity at the surface, and the viscosity increases as the temperature increases. The low initial viscosity helps to pump the fluid easily.

The HSLCM exhibits a thixotropic behavior because it is viscous under static condition and once dynamic condition is attained, the material viscosity will start to decrease because of its shear thinning property. The shear thinning was represented by a viscosity decrease with increasing shear rate, and such behavior resulted from the polymer molecules alignment [40]. The shear thinning during the fluid pumping is achieved by means of mixing of a novel amphoteric surfactant with sealant powder [41]. The thixotropic shear shinning behavior of the HSLCM provides many benefits such as placing the fluid downhole easily, preventing the gas migration, and reducing the fluid flow to the thief zones before the material solidification. 


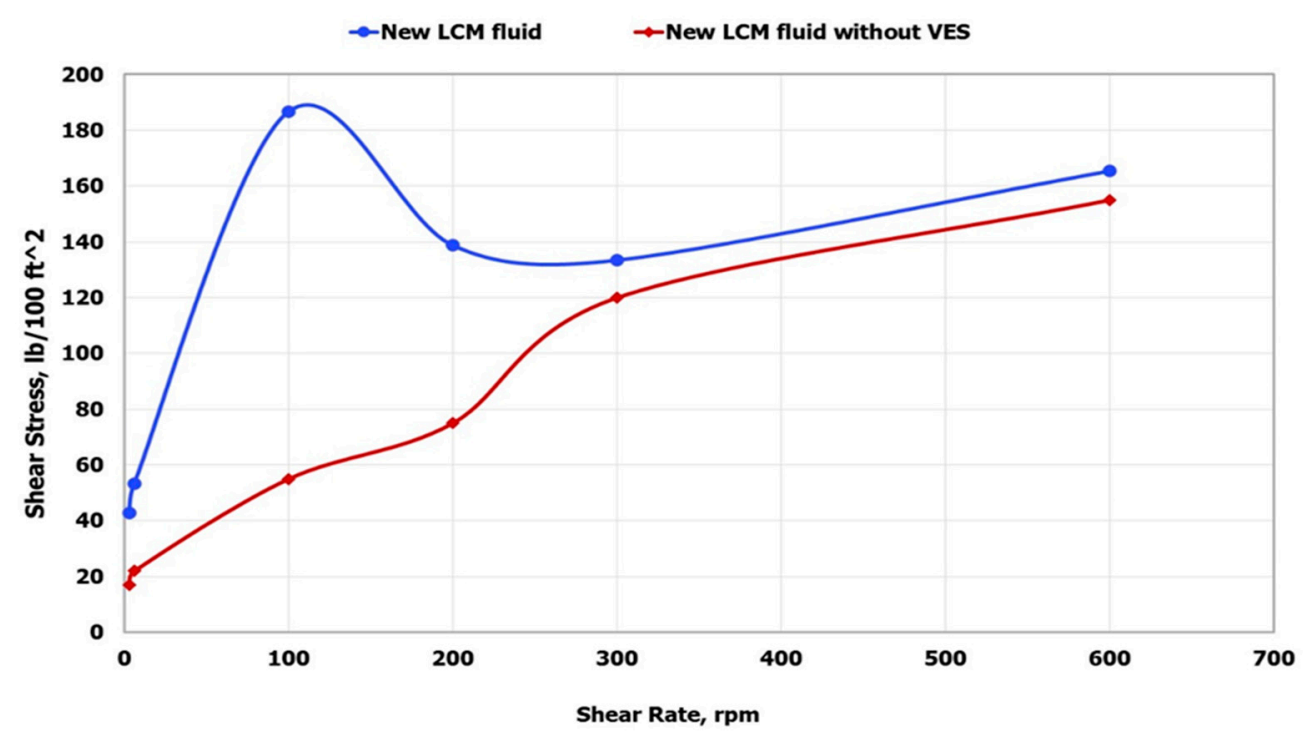

Figure 4. Shear-stress shear-rate behavior of the HSLCM fluid with and without the VES at room temperature $\left(80^{\circ} \mathrm{F}\right)$.

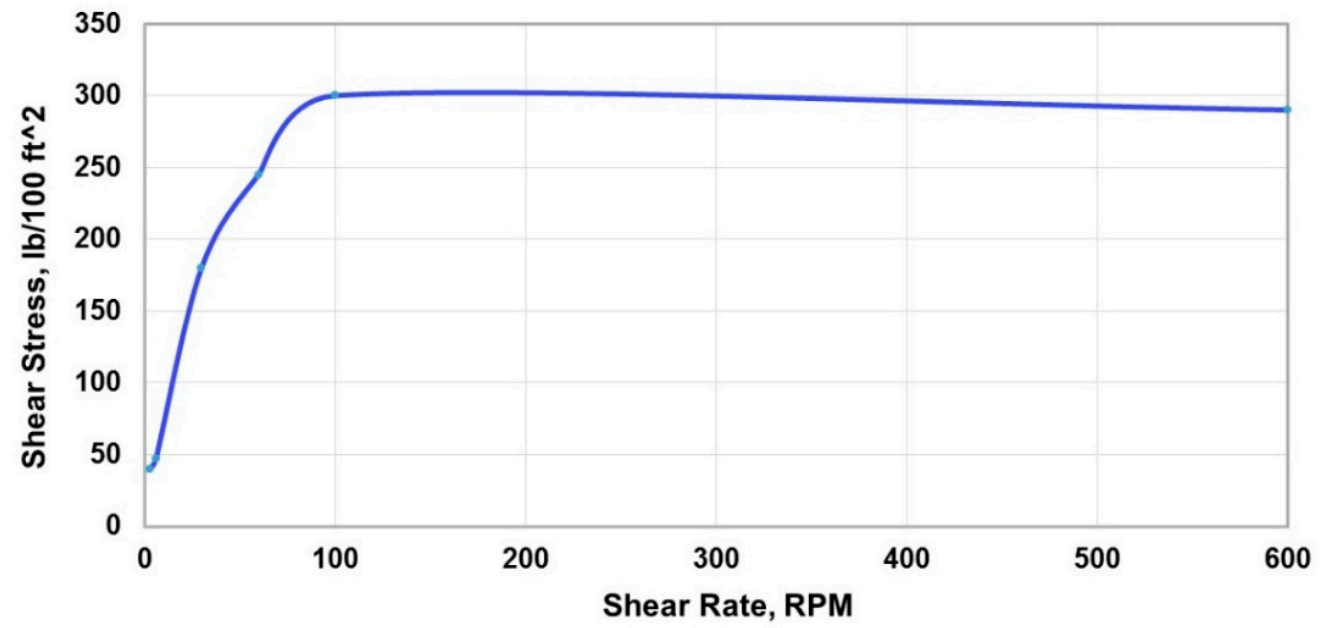

Figure 5. Shear-stress shear-rate for the HSLCM fluid with the VES at $175^{\circ} \mathrm{F}$.

It is a common practice to use a crosslinking polymer with a bridging material to form a thick gel for lost circulation cases. However, the cross-linked fluids do not have enough compressive strength to cure total losses. The new fluid composition does not contain cross-linked polymer. However, its thixotropic property that can be optimized according to the required pumping time, downhole pressure, and temperature conditions. 


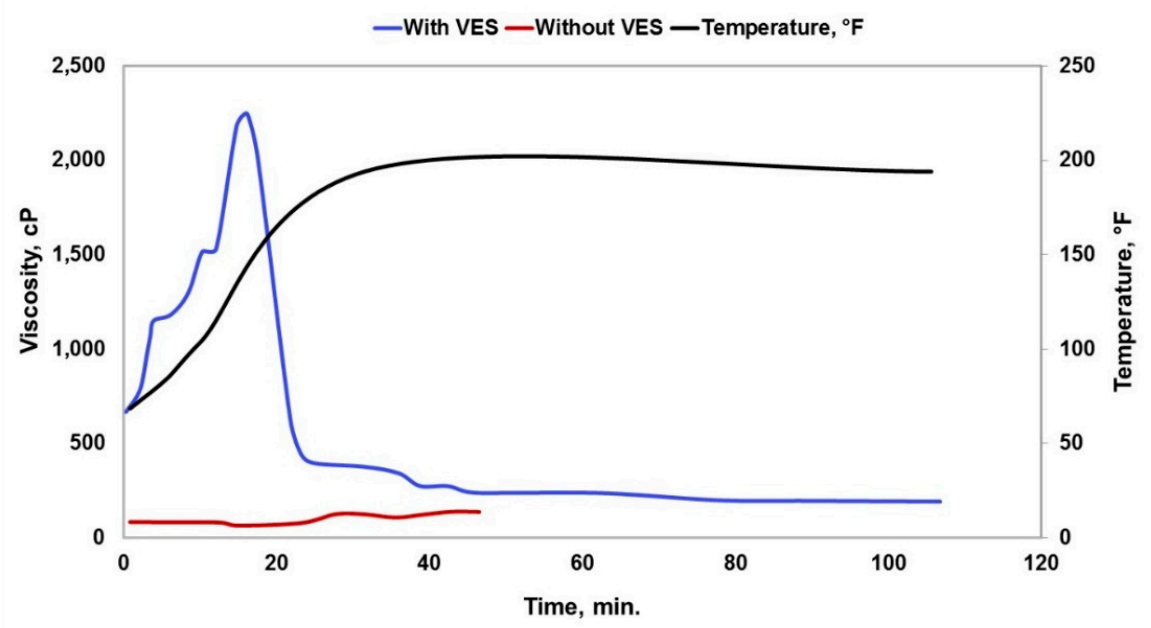

Figure 6. Viscosity Comparison for the HSLCM with and without VES at $200^{\circ} \mathrm{F}$.

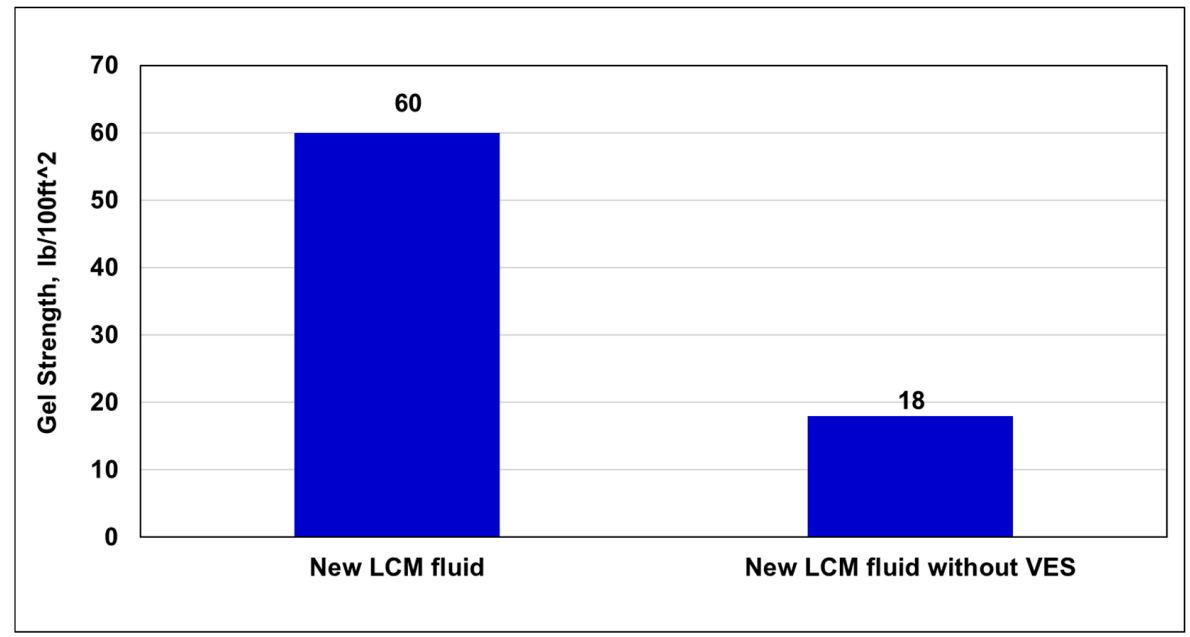

Figure 7. Gel strength (10-Second reading) of the HSLCM at the room temperature $\left(80^{\circ} \mathrm{F}\right)$.

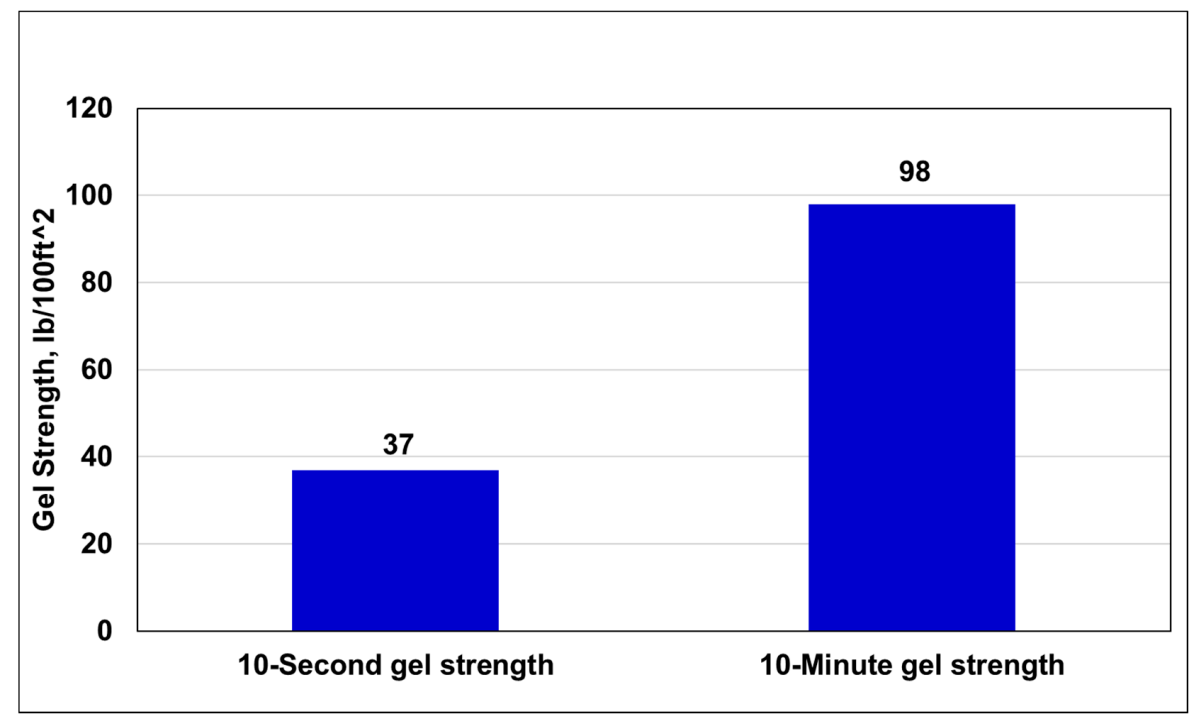

Figure 8. Gel strength of the HSLCM (with VES) at $175^{\circ} \mathrm{F}$. 


\subsection{Thickening Time Test}

The thickening time for the HSLCM was determined with pressurized consistometer and the results are shown for $12.5 \mathrm{ppg}$ fluid density in Table 2. The measurements were performed for temperature range from $125^{\circ} \mathrm{F}$ to $225^{\circ} \mathrm{F}$. In addition, the setting control additive was needed for better optimization of setting time, since it increases the thickening time of the HSLCM (12.5 ppg) fluid. This property can be optimized according to the required pumping time for field applications. The results showed that at $125^{\circ} \mathrm{F}$, the setting time was $2 \mathrm{~h}$ and $40 \mathrm{~min}$. For higher temperature of 225 ${ }^{\circ} \mathrm{F}$, the setting time decreased to $1 \mathrm{~h}$ and $16 \mathrm{~min}$, which is considered to be an acceptable time for LCM pumping operations.

Table 2. Thickening time for the HSLCM (12.5 ppg) at different temperatures.

\begin{tabular}{cc}
\hline Temperature $\left({ }^{\circ} \mathbf{F}\right)$ & Thickening Time (h:min) \\
\hline 125 & $2: 40$ \\
150 & $1: 40$ \\
175 & $1: 50$ \\
200 & $1: 40$ \\
225 & $1: 16$ \\
\hline
\end{tabular}

Figure 9 represents the thickening time for the HSLCM fluid at a density of $12.5 \mathrm{ppg}$ and $175^{\circ} \mathrm{F}$, it shows that the fluid is pumpable for up to $1 \mathrm{~h}$ and $50 \mathrm{~min}$.

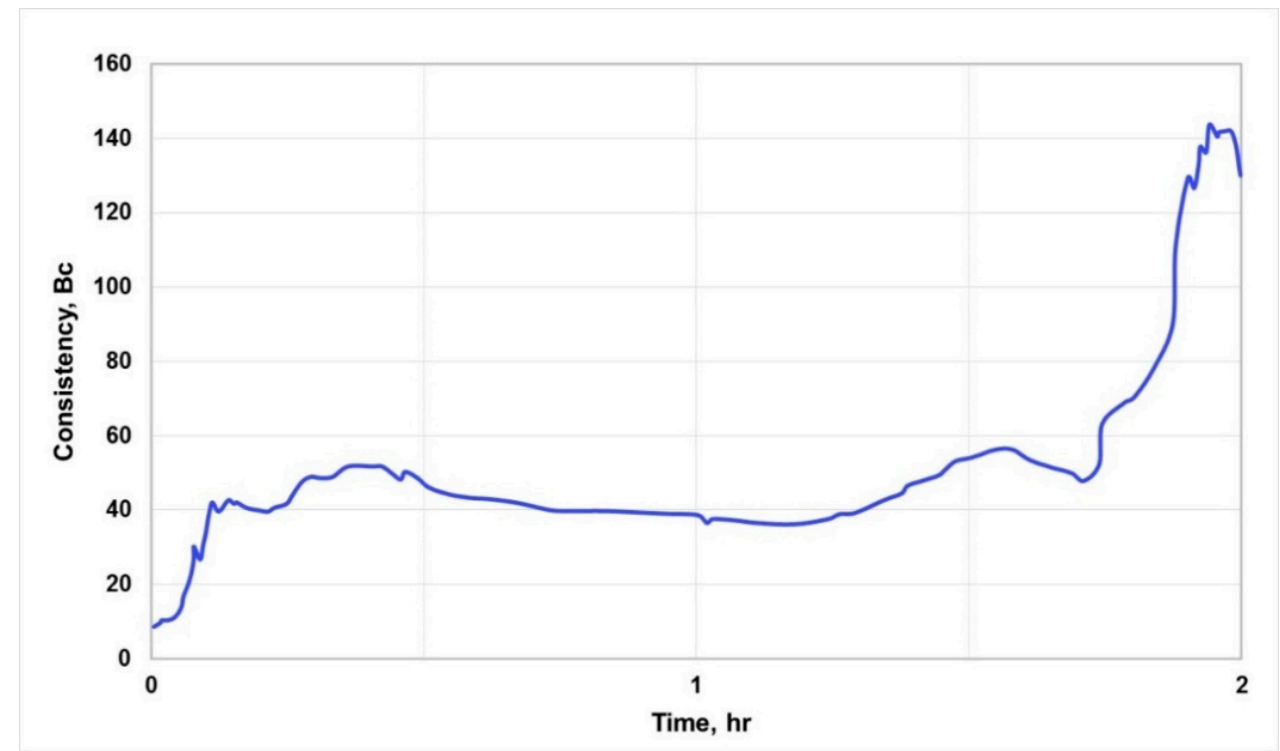

Figure 9. Thickening time for the HSLCM $(12.5 \mathrm{ppg})$ at $175^{\circ} \mathrm{F}$.

\subsection{Compressive Strength Test}

The compressive strength of the HSLCM (12.5 ppg density) at $175^{\circ} \mathrm{F}$ was recorded and plotted in Figure 10. The compressive strength of the HSLCM stabilized at about 732 psi after around $5 \mathrm{~h}$, and the experiment was extended for $25 \mathrm{~h}$. The compressive strength was evaluated for different formulations at different temperature. Table 3 lists the valued of the UCS after $24 \mathrm{~h}$ for different formulations. 


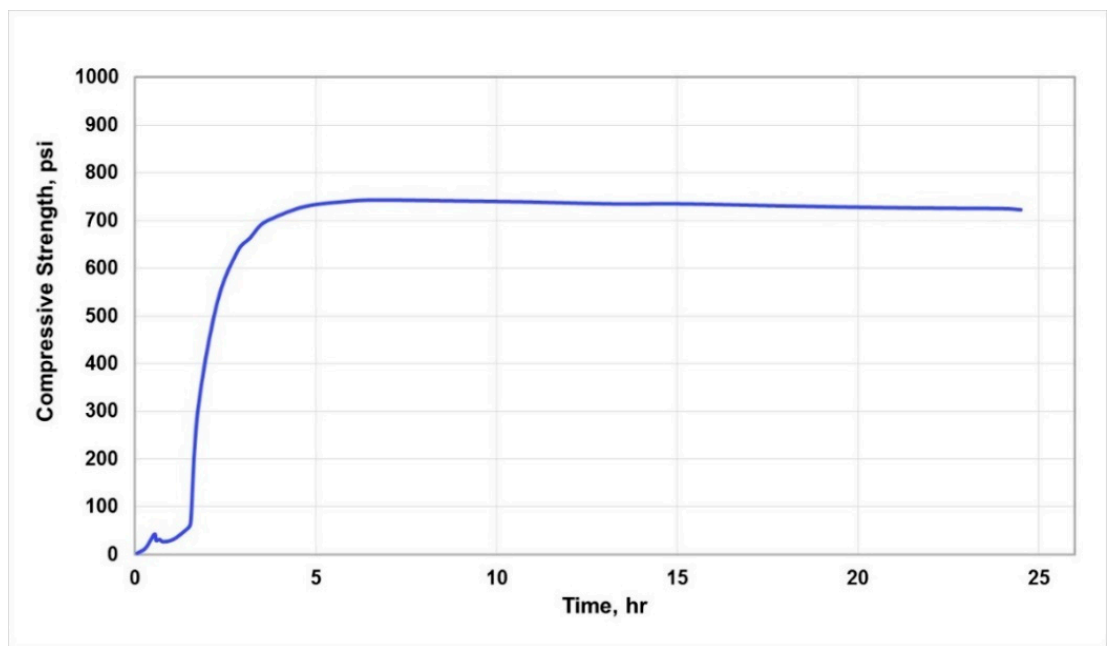

Figure 10. Compressive strength of the $\operatorname{HSLCM}(12.5 \mathrm{ppg})$ at $175^{\circ} \mathrm{F}$.

Table 3. UCA for the HSLCM (12.5 ppg) at different Temperatures.

\begin{tabular}{cc}
\hline Temperature $\left({ }^{\circ} \mathbf{F}\right)$ & UCA (psi) \\
\hline 125 & 1115 \\
150 & 718 \\
175 & 723 \\
200 & 447 \\
225 & 520 \\
\hline
\end{tabular}

\subsection{Acid Solubility Test}

The results of the acid solubility test showed that the solubility of the HSLCM is more than $90 \%$ when 15 wt. $\% \mathrm{HCl}$ solution is used. Table 4 represents the results of solubility test for the slurry with a density of $12.5 \mathrm{ppg}$ and where the solubility ratio was $96.6 \%$; this high solubility is important to ensure effective cleaning takes place after the lost circulation treatment.

Table 4. The HSLCM 12.5 ppg acid solubility results.

\begin{tabular}{cccccc}
\hline Acid Solubility & $\begin{array}{c}\text { Initial Weight } \\
\text { of the Cube (g) }\end{array}$ & $\begin{array}{c}\text { Acid Used (15 } \\
\text { wt.\% HCl) } \mathbf{( g )}\end{array}$ & $\begin{array}{c}\text { Time to } \\
\text { Dissolve (h) }\end{array}$ & $\begin{array}{c}\text { Residue } \\
\text { Left (g) }\end{array}$ & Solubility (\%) \\
\hline 2-inch Cube 12.5 ppg & 144.58 & 800.46 & 4 & 4.93 & 96.6 \\
\hline
\end{tabular}

\section{Field Testing and Application}

\subsection{Field Contamination Testing}

A batch mixing for the HSLCM was performed to mimic the field application conditions of ambient temperature that sometimes recorded higher values, and also a longer mixing time that might extend. The batch mixing test was conducted at a surface temperature of $113^{\circ} \mathrm{F}$ and extended for $4 \mathrm{~h}$. The results showed the fluid was mixed easily, and no fluid setting occurred because the temperature did not reach the setting temperature, as shown above in Table 2. When the temperature increased to $175^{\circ} \mathrm{F}$, the fluid set as designed setting time within $2 \mathrm{~h}$.

The fluid was also tested for the contamination with drilling mud to check the new LCM performance in the real field application. The test was performed with water-based mud (WBM) and oil-based mud (OBM). A KCl/Polymer system of 12.5 ppg was used for 10\% WBM contamination with new LCM fluid, and high performance water-based mud was used for 20\% WBM contamination and 
conventional $12.5 \mathrm{ppg}$ OBM for OBM contaminations. The results showed that the thickening time did not change significantly with mud system contamination.

\subsection{Field Application Case Study}

During drilling the $8 \frac{1}{2}$-in section through gas cap carbonate formations in the Middle East, lost circulation challenges were faced in many wells. Such challenges are because of the formation vugs that are linked with fractured networks. Common treatment for such lost circulations were applied in several cases as pumping series of LCM pills, cement plugs, sidetracking, and setting packers for isolation. However, such typical treatment techniques are expensive and time consuming and hence increases the drilling cost. From the offset wells that used the common treatment, there is a high probability of increasing the losses once the drilling is continued and the LCM is circulated.

During this case, the operator was using $10.7 \mathrm{ppg}$ calcium carbonate-based mud with $\mathrm{KCl}$ polymer. A sudden total circulation loss occurred at a depth of $5207 \mathrm{ft}$. The decision was made to keep a hydrostatic head across the gas cap to prevent any well control problem. The well was pumped with $12.5 \mathrm{ppg}$ at $60 \mathrm{bbl} / \mathrm{h}$ through the annulus. At the same time, three conventional LCM was prepared to treat such a total loss case and three pills were pumped. The conventional LCM, however, did not stop the total circulation loss, but only reduced the losses rate to partial return.

The HSLCM was prepared to cure that type of severe losses. The HSLCM shows thixotropic behavior that prevents further flow through the loss zone after squeezing. After the HSLCM fluid setting, it retains a compressive strength that isolates the loss zone from the wellbore and prevents loss circulation from occurring after continuing the drilling operation. The HSLCM provided the solution for the loss circulation case. Based on the lab testing and fluid design for the downhole condition, it was recommended to use $55 \mathrm{bbl}$ of the HSLCM. The drill pipe was pulled to the calculated pill top. It was observed that, during tripping out of the hole to the designed depth, an additional $25 \mathrm{bbl}$ were squeezed into the loss zone. The new LCM pills were pumped and allowed to set during pulling out of the hole to change the bottom hole assembly (BHA) as per the drilling program.

Figure 11 shows the setting time chart as the HSLCM set in $1 \mathrm{~h}$ and $15 \mathrm{~min}$. Figure 12 represents the compressive strength for the HSLCM at a downhole temperature of $200^{\circ} \mathrm{F}$. The BHA was run in the hole, washing down to the zone bottom with no static or dynamic losses. Once BHA reached the bottom, drilling was resumed to the total depth with no losses. The HSLCM application in that case allowed for curing the losses, protecting the cap rock section from damaging, and completing well drilling to the target quickly and effectively.

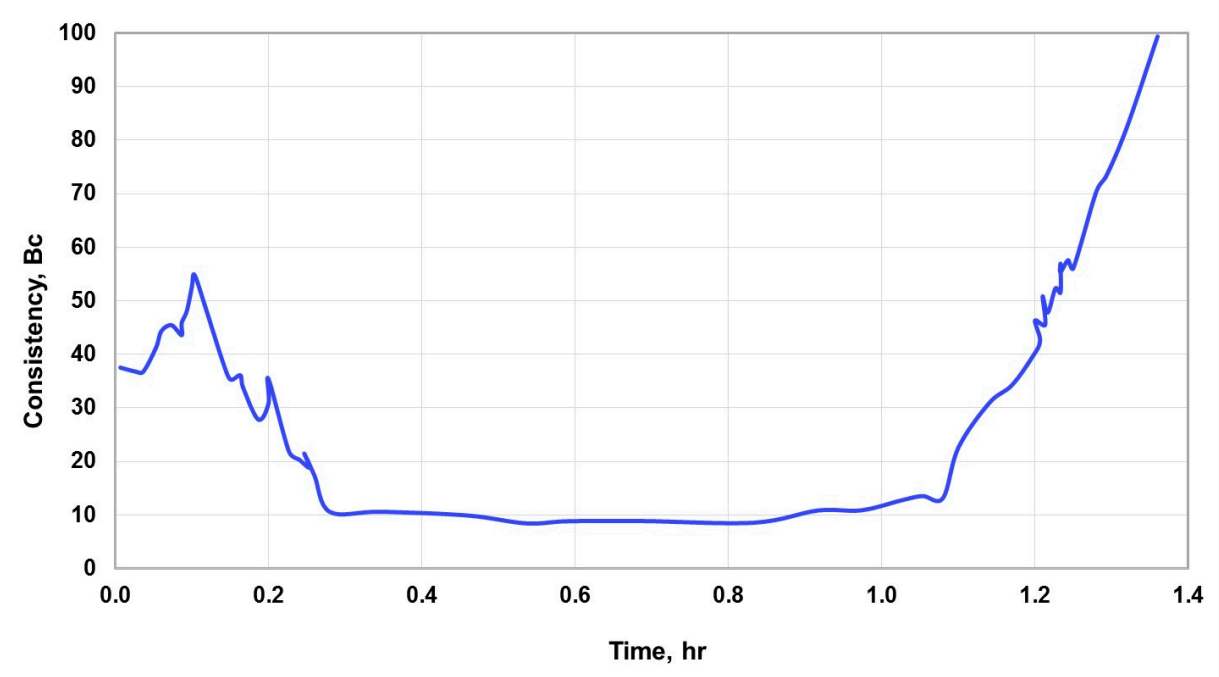

Figure 11. The setting time chart for the field case at $200^{\circ} \mathrm{F}$. 


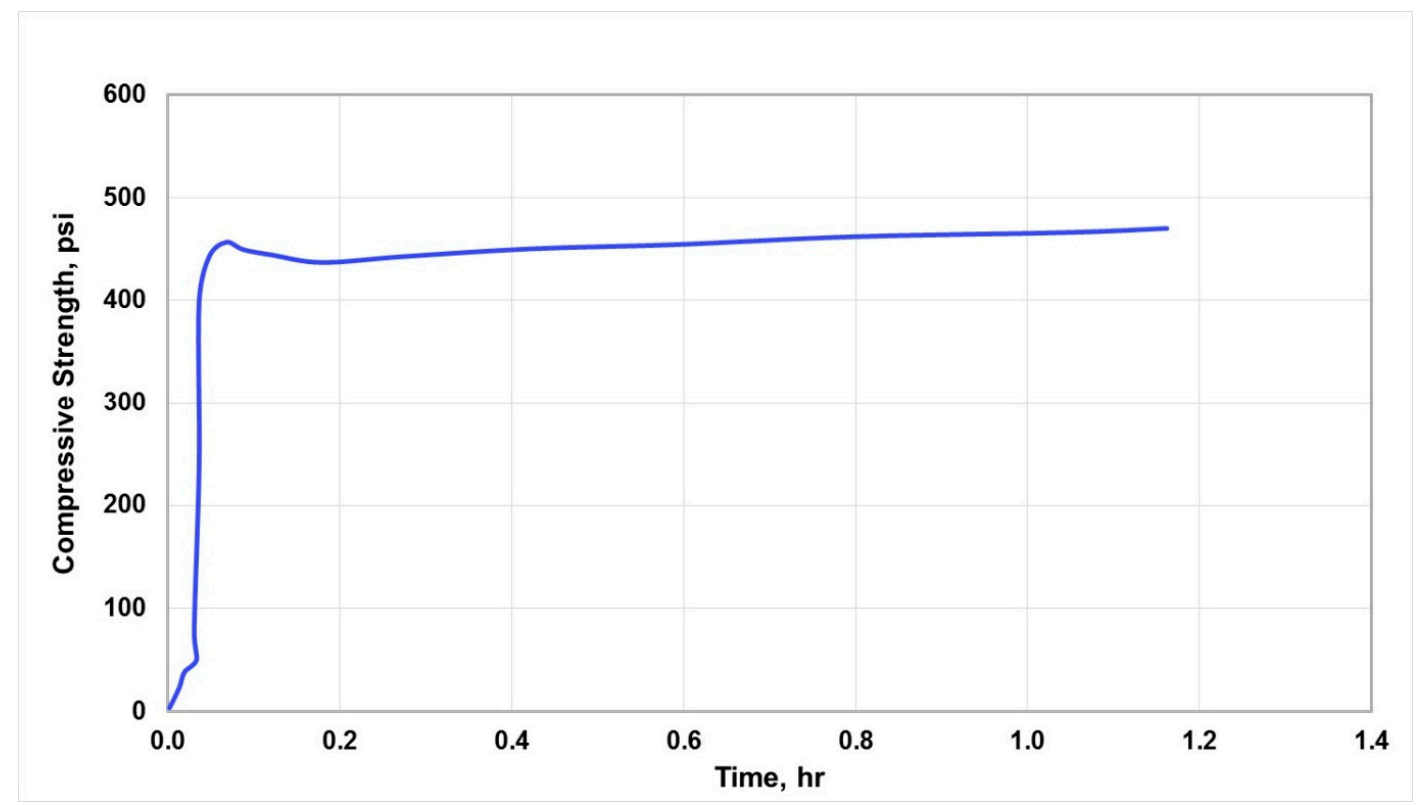

Figure 12. Compressive strength of the HSLCM at $200^{\circ} \mathrm{F}$.

\section{Conclusions}

In this study, the effectiveness of the novel high strength lost circulation material was evaluated. The performance of the HSLCM was evaluated in the laboratory by evaluating the rheology, setting time, compressive strength, acid solubility, and mud contaminations of the materials. Then, the observations of the field application when using the HSLCM were discussed. Based on the results of this study, the following conclusions can be made:

- The HSLCM has a thixotropic behavior that helps in placing the fluid down-hole easily, preventing gas migration, and resisting loss zones flow before LCM fluid setting.

- The HSLCM is customized and chemically controlled for the setting time.

- The new fluid has a high compressive strength and hence can be used as isolation plugs and bridging across the loss zone. Also, with the HSLCM, it is easy to complete drilling of the next section through the plug.

- The new LCM is clean and undamaged for reservoir sections, as there is no crosslinking gellants used. In addition, the acid soluble weighting agent showed a high solubility of more than $90 \%$ into the $15 \mathrm{wt} . \% \mathrm{HCl}$, and hence dissolved easily in acid after setting.

- The HSLCM was successfully used in the field to prevent the severe circulation loss where the conventional LCM failed to stop the losses.

Author Contributions: Conceptualization, S.E., P.S., and S.S.; methodology, P.S. and S.S.; validation, M.A. and S.S.; formal analysis, H.G., A.A, M.A.; investigation, S.E., P.S., and S.S.; resources, P.S., and S.S.; data curation, H.G.; writing-original draft preparation, H.G., A.A; writing-review and editing, S.E., H.G., and A.A.; visualization, M.A., P.S., and S.S.; supervision, S.E. All authors have read and agreed to the published version of the manuscript.

Funding: This research received no external funding .

Acknowledgments: The authors wish to acknowledge King Fahd University of Petroleum \& Minerals and Baker Hughes for giving a permission to publish this work.

Conflicts of Interest: The author declares no conflict of interest.

\section{References}

1. Miranda, C.R.; Oliveira, J.L.; Cavalcante, G.M.S.; d'Almeida, A.R.; Pereira, R.F.L.; Santos, R.L.L.; Surmas, R. Materials for Controlling Severe Lost Circulation-Laboratory Evaluation. In Proceedings 
of the SPE-185582-MS presented at SPE Latin America and Caribbean Petroleum Engineering Conference, Buenos Aires, Argentina, 17-19 May 2017. [CrossRef]

2. Lavrov, A. Lost Circulation Mechanisms and Solutions, 1st ed.; Gulf Professional Publishing: Amsterdam, The Netherlands, 2016; ISBN 9780128039410.

3. Ramasamy, J.; Amanullah, M. Novel Fibrous Lost Circulation Materials Derived from Deceased Date Tree Waste. In Proceedings of the SPE-187989-MS presented at SPE Kingdom of Saudi Arabia Annual Technical Symposium and Exhibition, Dammam, Saudi Arabia, 24-27 April 2017. [CrossRef]

4. Ramasamy, J.; Gooneratne, P.C.; Amanullah, M. Current Methods and Novel Solutions for Mitigating Lost Circulation. In Proceedings of the IPTC-19499-MS presented at International Petroleum Technology Conference, Beijing, China, 26-28 March 2019. [CrossRef]

5. Howard, G.C.; Scott, P. An Analysis and the Control of Lost Circulation. J. Pet. Technol. 1951, 3, $171-182$. [CrossRef]

6. Messenger, J.U. Lost Circulation; PennWell Corporation: Tulsa, OK, USA, 1981; ISBN 100878141758.

7. Al-Hameedi, A.T.T.; Alkinani, H.H.; Dunn-Norman, S.; Flori, R.E.; Hilgedick, S.A.; Amer, A.S.; Alsaba, M.T. Using Machine Learning to Predict Lost Circulation in the Rumaila Field, Iraq. In Proceedings of the SPE-191933-MS presented at SPE Asia Pacific Oil and Gas Conference and Exhibition, Brisbane, Australia, 23-25 October 2018. [CrossRef]

8. Chilingarian, G.V.; Vorabutr, P. Drilling and Drilling Fluids; Elsevier Scientific Publishing Co.: Amsterdam, The Netherlands, 1981.

9. Kumar, A.; Savari, S.; Jamison, D.E.; Whitfill, D.L. Lost Circulation Control and Wellbore Strengthening: Looking Beyond Particle Size Distribution. In Proceedings of the AADE-11-NTCE-21 presented at AADE National Technical Conference and Exhibition, Houston, TX, USA, 12-14 April 2011; Available online: http://www.aade.org/app/download/6857742304/aade-11-ntce-21.pdf (accessed on 30 November 2019).

10. Valverde, E.; Goodwin, A. Radio Frequency Identification (RFID)-Enabled Circulation Sub Precisely Spots Loss Circulation Material in Critical Interval. In Proceedings of the SPE-174950-MS presented at SPE Annual Technical Conference and Exhibition, Houston, TX, USA, 28-30 September 2015. [CrossRef]

11. White, R.J. Lost-circulation Materials and their Evaluation. In Proceedings of the API-56-352 Presented at Drilling and Production Practice, New York, NY, USA, 1 January 1956; Available online: https://www. onepetro.org/conference-paper/API-56-352 (accessed on 2 December 2019).

12. Jain, B.; Khattak, M.A.; Mesa, A.M.; Al Kalbani, S.; Meyer, A.; Aghbari, S.; Al-Salti, A.; Hennette, B.; Khaldi, M.; Al-Yaqoubi, A.; et al. Successful Implementation of Engineered Fiber Based Loss Circulation Control Solution to Effectively Cure Losses While Drilling, Cementing and Work over Operations in Oman. In Proceedings of the Paper SPE 166529 Presented at the SPE Annual Technical Conference and Exhibition, Society of Petroleum Engineers, New Orleans, LA, USA, 30 September-2 October 2013. [CrossRef]

13. Samsuri, A.; Phuong, B.T.N. Cheaper Cement Formulation for Lost Circulation Control. In Proceedings of the Paper IADC/SPE 77216 presented at Asia Pacific Drilling Technology, Jakarta, Indonesia, 9-11 September 2002. [CrossRef]

14. Rahman, S.; Marx, C. Laboratory Evaluation of Formation Damage Caused by Drilling Fluids and Cement Slurry. J. Can. Pet. Technol. 1991, 30. [CrossRef]

15. Bour, D.L.; Vinson, E.F.; Totten, P.L.; Waheed, A. Low-Density Acid-Removable Cement as a Solution for Lost Circulation across Producing Formation. In Proceedings of the Paper SPE 25543 presented at SPE Middle East Technical Conference and Exhibition, Manama, Bahrain, 3-6 April 1993. [CrossRef]

16. Seymour, B.; Santra, A. Detailed Laboratory Investigation of Acid Soluble Cements as Solution for Lost Circulation across the Producing Zones. In Proceedings of the SPE-166804-MS Presented at the Middle East Drilling Technology Conference and Exhibition, Dubai, UAE, 7-9 October 2013. [CrossRef]

17. Savari, S.; Whitfill, D.L.; Walker, J. Lost Circulation Management in Naturally Fractured Reservoirs. In Proceedings of the SPE-178165-MS presented at SPE/IADC Middle East Drilling Technology Conference and Exhibition, Abu Dhabi, UAE, 26-28 January 2016. [CrossRef]

18. Mansure, A.J. Polyurethane Grouting Geothermal Lost Circulation Zones. In Proceedings of the SPE-74556-MS presented at IADC/SPE Drilling Conference, Dallas, TX, USA, 26-28 February 2002. [CrossRef]

19. Shryock, S.H. Geothermal Well Cementing Technology. In Proceedings of the SPE-12454-MS Presented at the SPE Southeast Asia Show, Singapore, 12-14 February 1984. [CrossRef] 
20. Hilscher, L.W.; Clements, W.R. High-Temperature Drilling Fluid for Geothermal and Deep sensitive Formations. In Proceedings of the SPE-10737-MS Presented at the SPE California Regional Meeting, San Francisco, CA, USA, 24-26 March 1982. [CrossRef]

21. Griffith, J.E.; Nix, D.Q.; Boe, G.A. Reverse Circulation of Cement on Primary Jobs Increases Cement Column Height Across Weak Formations. In Proceedings of the SPE-25440-MS Presented at the SPE Production Operations Symposium, Oklahoma, OK, USA, 21-23 March 1993. [CrossRef]

22. Robert, M.; Bour, D.; Reed, S.; Hernandez, R. High-Temperature Wells with Lost-Circulation Demands and Reverse-Circulation Techniques Using Foamed-Cement Systems: Two Case Histories. SPE Drill. Completion 2005, 20, 133-140. [CrossRef]

23. Gupta, N.; Suhaimi, M.; Taty, B.T.; Meyer, A.; Forni, G.; de Crevoisier, L.; Commerçon, S. Novel Fiber-Based Lost Circulation Treatment Cured Total Losses in Depleted Zones in Emeraude Field. In Proceedings of the OMC-2015-261 presented at Offshore Mediterranean Conference and Exhibition, Ravenna, Italy, 25-27 March 2015; Available online: https://www.onepetro.org/conference-paper/OMC-2015-261 (accessed on 2 December 2019).

24. Suyan, K.M.; Baneriee, S.; Dasgupta, D. A Practical Approach for Preventing Lost Circulation wile Drilling. In Proceedings of the SPE-105251-MS is Presented at the Middle East Oil and Gas Sow and Conference, Manama, Bahrain, 11-14 March 2007. [CrossRef]

25. Priening, P.; Ali, M.; Jafeery, M.; Salazar, J.; Jain, B. Advanced Engineering Fiber technology-A Novel Solution to Care Lost Circulation during Drilling: Pakistan Case History. In Proceedings of the SPE-114069-MS Presented at Asia Pacific Drilling Technology Conference Exhibition, Jakarta, Indonesia, 25-27 August 2008. [CrossRef]

26. Droger, N.; Eliseeve, K.; Todd, L.; Ellis, C.; Salih, O.; Silko, N.; Fu, D.; Meyer, A.; Bermudez, R. Degradable Fiber Pill for Lost Circulation in Fractured Reservoir Sections. In Proceedings of the SPE-168024-MS Presented at the IADC/SPE Drilling Conference and Exhibition, Fort Worth, TX, USA, 4-6 March 2014. [CrossRef]

27. Savari, S.; Whitfill, D.; Kumar, A. Resilient Lost Circulation Material (LCM): A Significant factor in Effective Wellbore Strengthening. In Proceedings of the SPE-153154-MS Presented at the SPE Deepwater Drilling and Completions Conference, Galveston, TX, USA, 20-21 June 2012. [CrossRef]

28. Kumar, A.; Savari, S.; Whitfill, D.; Jamison, D. Wellbore Strengthening: The Less-Studied Properties of Lost-Circulation Materials. In Proceedings of the SPE-133484-MS Presented at the SPE Annual Technical Conference and Exhibition, Florence, Italy, 19-22 September 2010. [CrossRef]

29. Al-Awad, M.N.; Ka, F. Utilization of Shredded Waste Car Tyres as a Fracture Seal Material (FSM) in Oil and Gas Drilling Operations. J. Pet. Environ. Biotechnol. 2017, 8. [CrossRef]

30. Nasiri, A.; Ghaffarkhah, A.; Dijvejin, Z.A.; Mostofi, M.; Moraveji, M.K. Bridging performance of new eco-friendly lost circulation materials. Pet. Explor. Dev. 2018, 45, 1154-1165. [CrossRef]

31. Quinn, D.; Sunde, E.; Baret, J.F. Mechanism of a Novel Shear-Sensitive Plugging Fluid to Cure Lost Circulation. In Proceedings of the SPE-50722-MS Presented at the International Symposium on Oilfield Chemistry, Houston, TX, USA, 16-19 February 1999. [CrossRef]

32. Lecolier, E.; Herzhaft, B.; Rousseau, L.; Neau, L.; Quilien, B.; Kiedder, J. Development of a Nanocomposite Gel for Lost Circulation Treatment. In Proceedings of the SPE-94686-MS Presented at the SPE European Formation Damage Conference, Scheveningen, The Netherlands, 25-27 May 2005. [CrossRef]

33. Metcalf, A.S.; Nix, K.; Martinez-Guedry, J. Case Histories: Overcoming Lost Circulation during Drilling and Primary Cementing Operation Using and Environmentally Preferred System. In Proceedings of the SPE-140723-MS Presented at the Production and Operation Symposium, Oklahoma City, OK, USA, 27-29 March 2011. [CrossRef]

34. Jiang, G.; Deng, Z.; He, Y.; Li, Z.; Ni, X. Cross-linked polyacrylamide gel as loss circulation materials for combating lost circulation in high temperature well drilling operation. J. Pet. Sci. Eng. 2019, 181, 106250. [CrossRef]

35. Jadhav, R.; Patil, S. Acid-Soluble Thixotropic Cement System for Lost Circulation Challenges. In Proceedings of the SPE-193168-MS Presented at Abu Dhabi International Petroleum Exhibition \& Conference, Abu Dhabi, UAE, 12-15 November 2018. [CrossRef]

36. Luzardo, J.; Oliveira, E.P.; Derks, P.W.J.; Nascimento, R.V.; Gramatges, A.P.; Valle, R.; Inderberg, K. Alternative Lost Circulation Material for Depleted Reservoirs. In Proceedings of the OTC-26188-MS Presented at Offshore Technology Conference OTC Brasil, Rio de Janeiro, Brazil, 27-29 October 2015. [CrossRef] 
37. API. American Petroleum Institute: Specification for Material and Testing Well Cements; American Petroleum Institute: Northwest Washington, DC, USA, 1990.

38. API. American Petroleum Institute Recommended Practice for Testing Well Cements, 22nd ed.; API Recommended Practice 10B; American Petroleum Institute: Northwest Washington, DC, USA, 1997.

39. Umeokafor, C.V.; Joel, O.F. Modeling of Cement Thickening Time at High Temperatures with Different Retarder Concentrations. In Proceedings of the SPE-136973-MS Presented at the Nigeria Annual International Conference and Exhibition, Tinapa-Calabar, Nigeria, 31 July-7 August 2010. [CrossRef]

40. Powell, J.W.; Stagg, T.O.; Reiley, R.H.; Dobson, J. Thixotropic, Crosslinking Polymer/Borate/Salt Plug: Development and Application. In Proceedings of the SPE-22068-MS Presented at the International Arctic Technology Conference, Anchorage, AK, USA, 29-31 May 1991. [CrossRef]

41. Yadav, P.; Sarmah, P.; Jadhav, P.; Agrawal, G.; Kosander, B.; Tawat, N.A.; Addagalla, A. New Phase Transformation Fluid Based Loss Circulation Material: Hi-Strength, Year Round Use to Cure Severe to Total Loss in Reservoir and Non Reservoir Sections. In Proceedings of the SPE-183945-MS Presented at the SPE Middle East Oil \& Gas Show and Conference, Manama, UK, 6-9 March 2017. [CrossRef]

(C) 2020 by the authors. Licensee MDPI, Basel, Switzerland. This article is an open access article distributed under the terms and conditions of the Creative Commons Attribution (CC BY) license (http://creativecommons.org/licenses/by/4.0/). 